Article

\title{
Raman Spectroscopy and Single-Crystal High-Temperature Investigations of Bentorite, $\mathrm{Ca}_{6} \mathrm{Cr}_{2}\left(\mathrm{SO}_{4}\right)_{3}(\mathrm{OH})_{12} \cdot 26 \mathrm{H}_{2} \mathrm{O}$
}

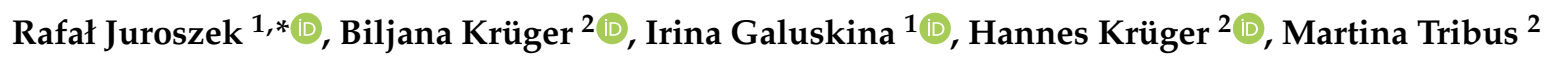 \\ and Christian Kürsten ${ }^{2}$ \\ 1 Institute of Earth Sciences, Faculty of Natural Sciences, University of Silesia, Będzińska 60, 41-205 Sosnowiec, \\ Poland; irina.galuskina@us.edu.pl \\ 2 Institute of Mineralogy and Petrography, University of Innsbruck, Innrain 52, 6020 Innsbruck, Austria; \\ Biljana.Krueger@uibk.ac.at (B.K.); Hannes.Krueger@uibk.ac.at (H.K.); Martina.Tribus@uibk.ac.at (M.T.); \\ Christian.Kuersten@student.uibk.ac.at (C.K.) \\ * Correspondence: rjuroszek@us.edu.pl; Tel.: +48-516-491-438
}

Received: 28 November 2019; Accepted: 27 December 2019; Published: 30 December 2019

check for updates

\begin{abstract}
The crystal structure of bentorite, ideally $\mathrm{Ca}_{6} \mathrm{Cr}_{2}\left(\mathrm{SO}_{4}\right)_{3}(\mathrm{OH})_{12} \cdot 26 \mathrm{H}_{2} \mathrm{O}$, a Cr${ }^{3+}$ analogue of ettringite, is for the first time investigated using $\mathrm{X}$-ray single crystal diffraction. Bentorite crystals of suitable quality were found in the Arad Stone Quarry within the pyrometamorphic rock of the Hatrurim Complex (Mottled Zone). The preliminary semi-quantitative data on the bentorite composition obtained by SEM-EDS show that the average $\mathrm{Cr} /(\mathrm{Cr}+\mathrm{Al})$ ratio of this sample is $>0.8$. Bentorite crystallizes in space group P31c, with $a=b=11.1927(5) \AA, c=21.7121(10) \AA$, $V=2355.60(18) \AA^{3}$, and $Z=2$. The crystal structure is refined, including the hydrogen atom positions, to an agreement index $\mathrm{R}_{1}=3.88 \%$. The bentorite crystal chemical formula is $\mathrm{Ca}_{6}\left(\mathrm{Cr}_{1.613} \mathrm{Al}_{0.387}\right)_{\Sigma 2}\left[\left(\mathrm{SO}_{4}\right)_{2.750}\left(\mathrm{CO}_{3}\right)_{0.499}\right]_{\Sigma 3.249}(\mathrm{OH})_{11.502} \sim 25.75 \mathrm{H}_{2} \mathrm{O}$. The Raman spectra of bentorite from two different localities exhibit the presence of the main stretching and bending vibrations related to the sulfate group at $983 \mathrm{~cm}^{-1}\left(v_{1}\right), 1109 \mathrm{~cm}^{-1}\left(v_{3}\right), 442 \mathrm{~cm}^{-1}\left(v_{2}\right)$, and $601 \mathrm{~cm}^{-1}\left(v_{4}\right)$. Moreover, the presence of bands assigned to the symmetric $\mathrm{Cr}(\mathrm{OH})_{6}{ }^{3-}$ stretching mode and hydroxyl deformation vibrations of $\mathrm{Cr}-\mathrm{OH}$ units at $\sim 540 \mathrm{~cm}^{-1}$ and $\sim 757 \mathrm{~cm}^{-1}$, respectively, may be used to distinguish between ettringite and bentorite. In situ high temperature single crystal XRD experiments show that the decomposition of bentorite starts at ca. $45^{\circ} \mathrm{C}$ and that a dehydroxylation product similar to metaettringite is formed.
\end{abstract}

Keywords: bentorite; ettringite group; SC-XRD; Raman spectroscopy; Hatrurim Complex; Israel

\section{Introduction}

Bentorite, with the ideal formula $\mathrm{Ca}_{6} \mathrm{Cr}_{2}\left(\mathrm{SO}_{4}\right)_{3}(\mathrm{OH})_{12} \cdot 26 \mathrm{H}_{2} \mathrm{O}$, was approved as a new mineral species by the Commission on New Minerals, Nomenclature and Classification (CNMNC) of the International Mineralogical Association (IMA) in 1979. The first report on this mineral stated that the powder diffraction pattern of bentorite was satisfactorily indexed by the analogy with ettringite $\mathrm{Ca}_{6} \mathrm{Al}_{2}\left(\mathrm{SO}_{4}\right)_{3}(\mathrm{OH})_{12} \cdot 26 \mathrm{H}_{2} \mathrm{O}[1]$.

Bentorite occurs only under specific conditions, and it is very sensitive to temperature and humidity changes, e.g., for the synthesis of $\mathrm{Cr}$ substituted ettringite in the laboratory, it is essential to use the appropriate alkalinity $(\mathrm{pH}=9.5-12.2)$ and reagent concentration in the solution (between 0.003 and $0.037 \mathrm{~mol} / \mathrm{dm}^{3}$ of $\mathrm{Cr}^{3+}$ ) as reported by Wieczorek-Ciurowa et al. [2]. This explains an extremely rare occurrence of bentorite in nature and difficulties in finding crystals with good quality and size for 
the structural (single crystal) study. Hitherto, this phase was found only in pyrometamorphic rocks of the Hatrurim Complex [1,3-5].

There are a few works concerning the ettringite-bentorite series. At the Ma'ale Adummim locality, hexagonal prismatic crystals (up to $300 \mu \mathrm{m}$ ) were found, which exhibited a gradual color variation from transparent to violet. This color variation corresponds to the ettringite-bentorite solid solution series up to a $\mathrm{Cr}$ end-member content of $60 \%$ [3]. Furthermore, structure refinements of the $\mathrm{Al}$ end-member (ettringite) and two $\mathrm{Cr}^{3+}$ bearing ettringite crystals (with maximum $\mathrm{Cr}$ occupation at the octahedral site $=27.5 \%$ ) were reported by Seryotkin et al. [4] for the same locality. Recently, the same group of authors performed a structural investigation of polycrystalline bentorite using synchrotron powder diffraction data, collected at room temperature (295 K) [5]. Their work confirmed that ettringite and bentorite were isostructural and that $\mathrm{Al}^{3+} \leftrightarrow \mathrm{Cr}^{3+}$ substitution took place without significant structural modifications.

Until now, the only temperature dependent investigation of bentorite was performed by Gross [1], where bentorite was concentrated for analysis by handpicking. The sample was proven to be $80 \%$ bentorite with some calcite and truscottite $(\mathrm{Ca}, \mathrm{Mn})_{14} \mathrm{Si}_{24} \mathrm{O}_{58}(\mathrm{OH})_{8} \cdot 2 \mathrm{H}_{2} \mathrm{O}$ impurities. Differential thermal analysis (DTA) revealed an endothermic peak with a maximum at $155^{\circ} \mathrm{C}$. Furthermore, thermogravimetric analysis (TGA) exhibited a continuous weight decrease between 60 and $255^{\circ} \mathrm{C}$ [1]. Thermogravimetric measurements of pure $\mathrm{Cr}^{3+}$ bentorite were done earlier by Drebushchak et al. [6] They observed a total mass loss of $38.83 \mathrm{wt} \%$ for bentorite in the temperature range $20-800{ }^{\circ} \mathrm{C}$.

In this paper, we present the results of the first single crystal structure refinement of bentorite with $80 \% \mathrm{Cr}^{3+}$ occupation at the octahedral site. Moreover, an in situ high temperature single crystal XRD study reveals the onset of the decomposition of bentorite at $45{ }^{\circ} \mathrm{C}$ and the formation of a dehydroxylation product similar to "metaettringite" [7].

\section{The Occurrence and Paragenesis of Bentorite}

Dark-violet, prismatic bentorite crystals up to $150 \mu \mathrm{m}$ in size, associated with calcite and ettringite, were found in low temperature veins within spurrite marble in the Arad Stone Quarry in the Negev Desert, Israel (Figure 1a,b). The studied rocks belonged to the pyrometamorphic Hatrurim Complex (Mottled Zone), which is distributed on both sides of the Dead Sea Transform Fault [5,8-14]. Besides the main rock forming minerals, spurrite and calcite, the minor concentrations of ye'elimite, shulamitite-sharyginite, brownmillerite, and fluorapatite-fluorellestadite were identified in the analyzed samples. Accessory minerals were represented by baryte, gibbsite, hydrocalumite, sphalerite, and pyrite. These spurrite marbles, commercially known as "Arad marble", were mined as raw material for building stones and floor tiles. The age of the sedimentary protolith was estimated based on fossils, which were typical of the Middle to Upper Maastrichtian $[10,13]$. The temperature of spurrite formation at ambient pressure was estimated between $650{ }^{\circ} \mathrm{C}$ and $800{ }^{\circ} \mathrm{C}$ [15-17]. Most of these rocks were intensively altered due to low temperature hydrothermal and weathering processes. They were mainly replaced by Ca silicate hydrates, zeolites, aragonite, gypsum, hydrogarnets, and ettringite [18].

Minerals of the ettringite-bentorite series were also identified at Ma'ale Adummim locality in the territory of Palestine. This location composed of high temperature rock, which occurred within medium height hills, is a part of the Hatrurim Complex as well (Figure 1c). Those crystals together with blue afwillite, thaumasite, ettringite, calcite, Ca silicate hydrates, and minerals of the baryte-hashemite series form the low temperature hydrothermal assemblages in the hosted gehlenite-flamite rocks (Figure 1d). The uniqueness of these crystals is that the difference in color related to the variable $\mathrm{Al} / \mathrm{Cr}$ ratio allowed us to recognize the members of this mineral series within one crystal. In contrast to the bentorite samples from Arad Stone, crystals from Ma'ale Adummim were larger $(\sim 300 \mu \mathrm{m})$ and well-shaped. This seems related to the crystallization conditions, as these crystals occurred in small cracks and cavities, mostly at the surface of blue spherical afwillite aggregates (Figure 1d), and did not form intergrowths like the bentorite crystals in thin veins from Arad Stone samples (Figure 1b). 

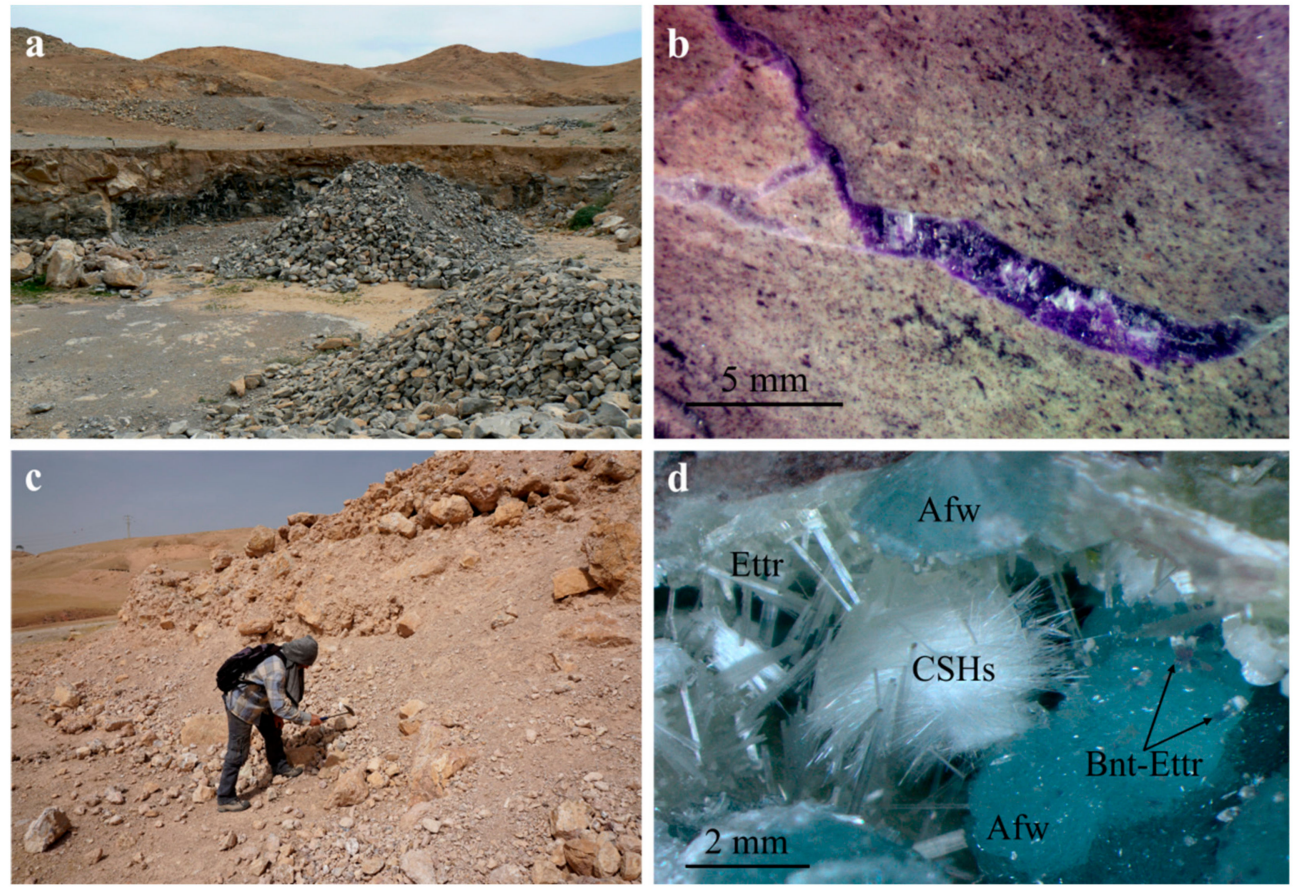

Figure 1. View of Arad Stone Quarry in the Negev Desert, Israel (a), and dark-violet bentorite vein in calcite-spurrite marble (b). View of Ma'ale Adummim locality, Palestine (c), and low temperature hydrothermal mineral assemblages within the small cavity in the hosted gehlenite-flamite rock (d). Afw, afwillite; Bnt-Ettr, minerals of bentorite-ettringite series; Ettr, ettringite; CSHs, Ca silicate hydrates.

\section{Materials and Methods}

The preliminary chemical composition, mineral association, and crystal morphology of bentorite from the Arad Stone Quarry and ettringite-bentorite mineral series from Ma'ale Adummim (for comparison) were examined using a scanning electron microscope Phenom XL (PhenomWorld, ThermoFisher Scientific, Eindhoven, The Netherlands) equipped with an EDS (energy dispersive X-ray spectroscopy) detector (Institute of Earth Sciences, Faculty of Natural Sciences, University of Silesia, Sosnowiec, Poland). Bentorite single crystals were mounted on carbon tape and sputtered with carbon. The chemical composition measurements were performed at high vacuum $(1 \mathrm{~Pa})$, with a beam voltage of $15 \mathrm{kV}$ and working distance $6 \mathrm{~mm}$. Point beam mode with the accumulation time of spectra of $10 \mathrm{~s}$ was chosen.

The Raman spectra of bentorite and ettringite from the Arad Stone Quarry and minerals of bentorite-ettringite series from Ma'ale Adummim were recorded on a WITec alpha 300R Confocal Raman Microscope (WITec, Ulm, Germany) (Institute of Earth Sciences, Faculty of Natural Sciences, University of Silesia, Sosnowiec, Poland) equipped with an air cooled solid laser of $488 \mathrm{~nm}$ and a $\mathrm{CCD}$ camera operating at $-61^{\circ} \mathrm{C}$. The laser radiation was coupled to a microscope through a single mode optical fiber with a diameter of $3.5 \mu \mathrm{m}$. An air Zeiss (LD EC Epiplan-Neofluan DIC-100/0.75NA) objective was used. Raman scattered light was focused by an effective pinhole size of about $30 \mu \mathrm{m}$ and a monochromator with a $600 \mathrm{~mm}^{-1}$ grating. The power of the laser at the sample position was $8-10 \mathrm{~mW}$. Integration times of $5 \mathrm{~s}$ with the accumulation of $20 \mathrm{scans}$ and a resolution of $3 \mathrm{~cm}^{-1}$ were chosen. The monochromator was calibrated using the Raman scattering line of a silicon plate $\left(520.7 \mathrm{~cm}^{-1}\right)$. Spectra processing such as baseline correction and smoothing was performed using the Spectracalc software package GRAMS (Galactic Industries Corporation, NH, USA). The Raman bands were fitted using a Gauss-Lorentz cross-product function with the minimum number of component bands used for the fitting process.

The single crystal X-ray diffraction study was carried out on a dark-violet crystal of bentorite $(0.19 \times 0.16 \times 0.12 \mathrm{~mm}$ from the Arad Stone Quarry), using a Rigaku Oxford Diffraction Gemini $\mathrm{R}$ 
Ultra diffractometer $(\mathrm{MoK} \alpha, \lambda=0.71073 \AA$ ) , equipped with a Ruby CCD detector and a graphite monochromator (Institute of Mineralogy and Petrography, University of Innsbruck, Austria). Data reduction and face based absorption correction after Clark and Reid [19] were processed using CrysAlisPro (Rigaku Oxford Diffraction, Yarnton, Oxforshire, UK) [20]. Experimental data and refinement details are summarized in Table 1.

Table 1. Parameters for X-ray data collection and crystal structure refinement for bentorite from the Arad Stone Quarry, Israel.

\begin{tabular}{|c|c|}
\hline \multicolumn{2}{|r|}{ Crystal Data } \\
\hline Refined chemical composition & $\mathrm{C}_{0.499} \mathrm{H}_{60} \mathrm{Al}_{0.387} \mathrm{Ca}_{6} \mathrm{Cr}_{1.613} \mathrm{O}_{49.725} \mathrm{~S}_{2.75}$ \\
\hline Crystal system & trigonal \\
\hline Space group & $P 31 c$ \\
\hline Unit cell dimensions & $a=11.1927(5) \AA$ \\
\hline & $b=11.1927(5) \AA$ \\
\hline & $c=21.7121(10) \AA$ \\
\hline Unit cell volume & $2355.60(18) \AA^{3}$ \\
\hline Formula weight & 1285 \\
\hline Density (calculated) & $1.8115 \mathrm{~g} / \mathrm{cm}^{3}$ \\
\hline $\mathrm{Z}$ & $2^{0}$ \\
\hline Crystal size & $0.19 \times 0.16 \times 0.12 \mathrm{~mm}$ \\
\hline \multicolumn{2}{|r|}{ Data Collection } \\
\hline Diffractometer & four-circle diffractometer, Rigaku Oxford Diffraction Gemini R Ultra \\
\hline Radiation wavelength & $0.71073 \AA$ \\
\hline min. and max. theta $\left(^{\circ}\right)$ & $3.53,29.6$ \\
\hline Time of exposure & $130 \mathrm{~s}$ \\
\hline & $-14 \leq h \leq 15$ \\
\hline Reflection ranges & $\begin{array}{l}-13 \leq k \leq 13 \\
-29 \leq l \leq 26\end{array}$ \\
\hline \multicolumn{2}{|c|}{ Refinement of Structure } \\
\hline Reflection measured & 38,295 \\
\hline No. of unique reflections & 3998 \\
\hline No. of observed unique reflections $[I>3 \sigma(I)]$ & 2714 \\
\hline Refined parameters & 248 \\
\hline $\mathrm{R}_{\text {int }}$ & 0.046 \\
\hline $\mathrm{R}_{1}$ & 0.0388 \\
\hline Goof & 1.91 \\
\hline$\Delta \rho_{\min }\left(\mathrm{e} \AA^{-3}\right)$ & -0.81 \\
\hline$\Delta \rho_{\max }\left(\mathrm{e} \AA^{-3}\right)$ & 1.34 \\
\hline
\end{tabular}

The structure refinement was carried out using Jana2006 [21]. The crystal was subjected to racemic twinning, which was accounted for in the structure refinement. All atoms, except hydrogen, and the T3 (C3) site (low occupation) were modeled using anisotropic displacement parameters. Further, all $\mathrm{H}$-atoms of the $\mathrm{OH}$-groups and $\mathrm{H}_{2} \mathrm{O}$ were located in a difference Fourier map. The coordinates of the $\mathrm{H}$-atoms were refined with restrained $\mathrm{O}-\mathrm{H}$ distances, and their displacement parameters $\left(\mathrm{U}_{\text {iso }}\right)$ were set to $1.2 \times \mathrm{U}_{\mathrm{eq}}$ of the corresponding oxygen atoms. The final atom coordinates $(\mathrm{x}, \mathrm{y}, \mathrm{z})$, equivalent isotropic displacement parameters $\left(\mathrm{U}_{\mathrm{eq}}, \AA^{2}\right)$, and occupancies were summarized in Supplemental Table S1. Anisotropic displacement parameters $\left(\AA^{2}\right)$ are given in Supplemental Table S2.

For the in situ high temperature investigations, a violet prismatic crystal (from the Arad Stone Quarry) with good optical quality was selected. The crystal was fixed in a $0.1 \mathrm{~mm}$ (outer diameter) fused quartz capillary. The X-ray diffraction data collection was performed with a Stoe IPDS-II imaging plate diffractometer using graphite monochromatized $\mathrm{MoK} \alpha$ radiation and a crystal to detector distance of $100 \mathrm{~mm}$ (Institute of Mineralogy and Petrography, University of Innsbruck, Austria). The diffractometer was equipped with a Heatstream high temperature attachment (Stoe \& Cie $\mathrm{GmbH}$, Darmstadt, Germany), which used an open flow of nitrogen to subject the crystal to elevated temperatures. A detailed description of the experimental setup and temperature calibration procedure was reported by Krüger and Breil [22]. A hemisphere of the reciprocal space was collected every $5{ }^{\circ} \mathrm{C}$, 
between 30 and $95^{\circ} \mathrm{C}$, using $\omega$-scans with a step size of $1^{\circ}$ and 5 min of exposure per frame. The total time of the data collection at one temperature was ca. $20 \mathrm{~h}$ (including the image plate read-out and erase phase). Integration of the data and reconstruction of precession like sections of the reciprocal space were done with X-Area [23].

The scanning electron microscopy investigation of the bentorite crystal after the HT XRD experiment was performed using a Jeol JSM-6010LV (Institute of Mineralogy and Petrography, University of Innsbruck, Innsbruck, Austria). The sample was Au sputtered, and the measurements were performed at high vacuum, with an acceleration voltage of $10 \mathrm{kV}$ and a working distance of $43 \mathrm{~mm}$.

\section{Results}

\subsection{Chemical Composition}

The normalized composition data of bentorite obtained using low intensity SEM-EDS are given in Table 2. The EDS spectra of bentorite from the Arad Stone Quarry for 10 analyses showed the ratio $\mathrm{Cr} /(\mathrm{Cr}+\mathrm{Al})$ in the range $0.8-0.9$. The average $\mathrm{Cr} /(\mathrm{Cr}+\mathrm{Al})$ proportion was equal to 0.85 . The calculated formula was $\mathrm{Ca}_{6.00}\left(\mathrm{Cr}_{1.71} \mathrm{Al}_{0.23} \mathrm{Si}_{0.06}\right)\left(\mathrm{SO}_{4}\right)_{3}(\mathrm{OH})_{12} \cdot 26 \mathrm{H}_{2} \mathrm{O}$.

Table 2. The normalized composition of bentorite.

\begin{tabular}{cccc}
\hline & \multicolumn{3}{c}{ Arad Stone Quarry } \\
\cline { 2 - 4 } wt \% & Mean & S.D. & Range \\
\cline { 2 - 4 } & $\mathbf{n}=\mathbf{1 0}$ & $17.79-18.93$ \\
$\mathrm{SO}_{3}$ & 18.48 & 0.32 & $0.13-0.50$ \\
$\mathrm{SiO}_{2}$ & 0.29 & 0.12 & $0.42-1.42$ \\
$\mathrm{Al}_{2} \mathrm{O}_{3}$ & 0.90 & 0.32 & $9.31-11.20$ \\
$\mathrm{Cr}_{2} \mathrm{O}_{3}$ & 10.00 & 0.56 & \\
$\mathrm{CaO}$ & 25.89 & 0.83 & \\
$\mathrm{H}_{2} \mathrm{O}^{\mathrm{a}}$ & 44.44 & & \\
$\mathrm{Total}$ & 100.00 & & \\
& $\mathrm{Calculated}$ on 8 framework cations \\
\hline $\mathrm{S}^{6+}$ & 3.00 & \\
$\mathrm{Si}^{4+}$ & 0.06 & \\
$\mathrm{Al}^{3+}$ & 0.23 & \\
$\mathrm{Cr}^{3+}$ & 1.71 & \\
$\mathrm{Ca}^{2+}$ & 6.00 & \\
$\mathrm{H}_{2} \mathrm{O}$ & 52.00 & \\
$\mathrm{OH}^{+}$ & 12.00 &
\end{tabular}

${ }^{\text {a }} \mathrm{H}_{2} \mathrm{O}$ content is calculated on the ideal composition $\mathrm{Ca}_{6} \mathrm{M}_{2}\left(\mathrm{SO}_{4}\right)_{3}(\mathrm{OH})_{12} \cdot 26 \mathrm{H}_{2} \mathrm{O}$, and the total is normalized to $100 \% ; \mathrm{n}=$ number of analyses; S.D. = standard deviation.

\subsection{Raman Spectroscopy}

The Raman spectra of ettringite and bentorite from Arad Stone in the 100-1800 $\mathrm{cm}^{-1}$ and $3000-3800 \mathrm{~cm}^{-1}$ ranges are shown in Figure 2a,b, respectively. The bands at $983 \mathrm{~cm}^{-1}$ in bentorite and $993 \mathrm{~cm}^{-1}$ in ettringite, assigned to the $v_{1}$ symmetric stretching vibrations of $\left(\mathrm{SO}_{4}\right)^{2-}$, were dominant in both of the Raman spectra. The position of this band in the ettringite spectrum corresponded to the previously published data for the synthetic and natural samples [24-27]. In the bentorite spectrum, this band was shifted to lower wavenumbers. Asymmetric stretching vibrations $v_{3}$ of $\left(\mathrm{SO}_{4}\right)^{2-}$ group were exhibited as bands at $1109 \mathrm{~cm}^{-1}$ in bentorite and at $1128 \mathrm{~cm}^{-1}$ in ettringite. The full width of bands related to the stretching vibrations of the sulfate group was broader in ettringite than in bentorite. The Raman bands at $442 \mathrm{~cm}^{-1}$ in bentorite and at $446 \mathrm{~cm}^{-1}$ in ettringite were ascribed to the $v_{2}\left(\mathrm{SO}_{4}\right)^{2-}$ symmetric bending modes. In the ettringite spectrum, the band at $622 \mathrm{~cm}^{-1}$ corresponded 
to the asymmetric bending vibration $v_{3}$ of the $\left(\mathrm{SO}_{4}\right)^{2-}$ group, whereas in bentorite, the band related to this vibration was at $601 \mathrm{~cm}^{-1}$. We assigned the $547 \mathrm{~cm}^{-1}$ and $857 \mathrm{~cm}^{-1}$ bands, observed in the ettringite spectrum, to the $\mathrm{Al}-\mathrm{OH}$ stretching and bending vibration of the $\mathrm{Al}(\mathrm{OH})_{6}{ }^{3-}$ unit, respectively, similar to previous reports $[24,25,27]$. Thus, the bands at 537 and $757 \mathrm{~cm}^{-1}$ in bentorite were most likely related to the vibration modes of $\mathrm{Cr}-\mathrm{OH}$ in $\mathrm{Cr}(\mathrm{OH})_{6}{ }^{3-}[5,28]$. Frost et al. [26], analyzing the spectra of natural ettringite, assigned the band at $\sim 760 \mathrm{~cm}^{-1}$ to the hydroxyl deformation mode of $\mathrm{Al}-\mathrm{OH}$ units. Moreover, in $\mathrm{Zn} / \mathrm{Cr}$ hydrotalcite, bands in the $754-769 \mathrm{~cm}^{-1}$ range were attributed to the hydroxyl deformation modes associated with $\mathrm{Cr}-\mathrm{OH}$ units [29]. Therefore, in the case of different types of elements occupying the octahedral site in ettringite and bentorite structures, we suggested assigning the band at $757 \mathrm{~cm}^{-1}$ in bentorite to the hydroxyl deformation vibration of $\mathrm{Cr}-\mathrm{OH}$ units. The additional bands observed at $344 \mathrm{~cm}^{-1}$ and below $300 \mathrm{~cm}^{-1}$ were related to the $\mathrm{Ca}-\mathrm{O}$ and lattice vibrations, respectively.

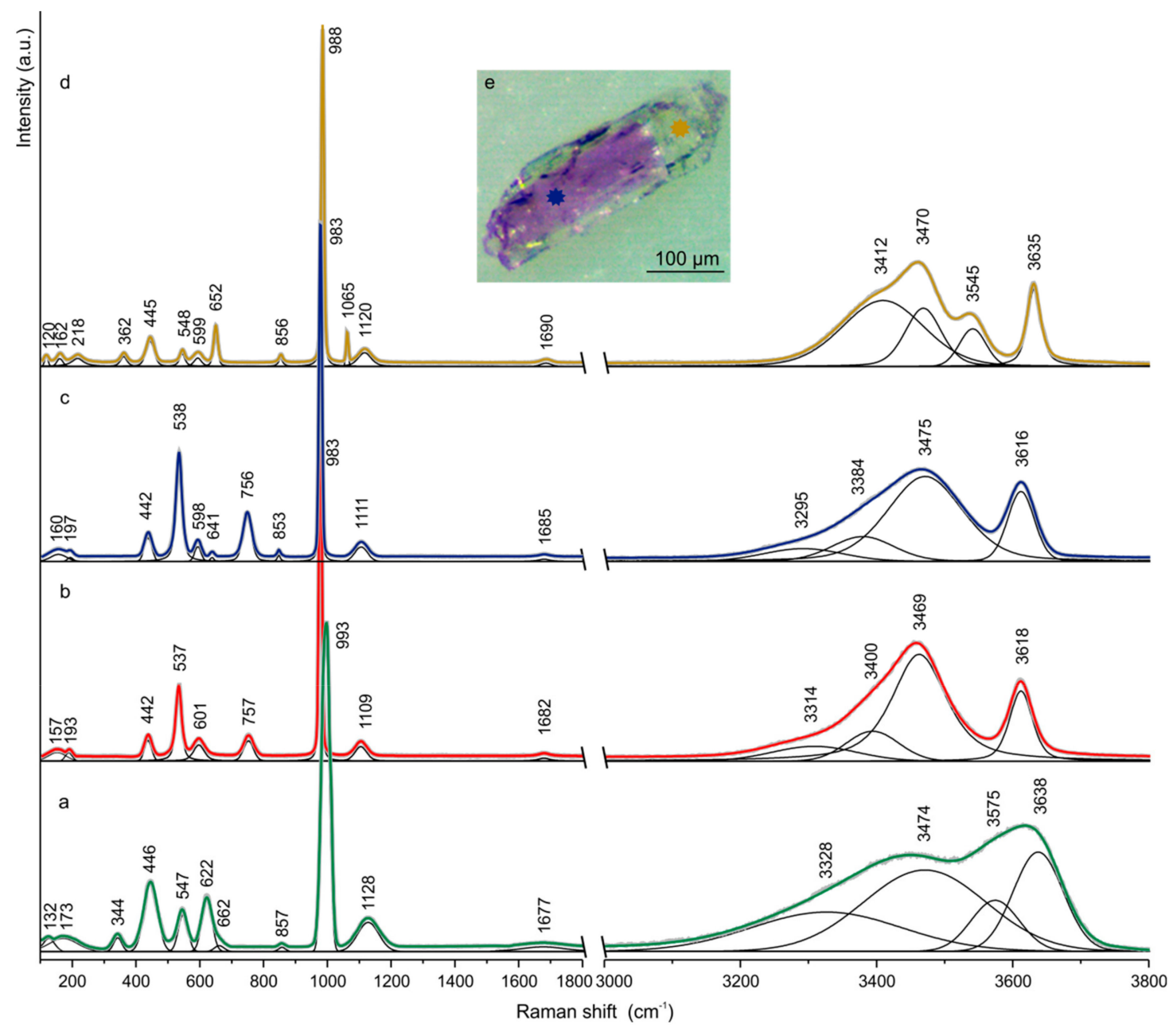

Figure 2. Raman spectra of ettringite (a) and bentorite (b) from the Arad Stone Quarry and bentorite (dark-violet part) (c) and ettringite (transparent part) (d) from Ma'ale Adummim locality (the crystal is shown at the top of (e) blue and yellow stars represent the spots, where Spectra c and d were recorded.

In the Raman spectrum of bentorite in the $3000-3800 \mathrm{~cm}^{-1}$ range, there was a broad band centered at $3469 \mathrm{~cm}^{-1}$ with two shoulders at 3400 and $3314 \mathrm{~cm}^{-1}$ and an intense band at $3618 \mathrm{~cm}^{-1}$ (Figure $2 \mathrm{~b}$ ). The first three bands were related to the $\mathrm{H}_{2} \mathrm{O}$ stretching modes, while the last one was attributed to $\mathrm{OH}$ stretching vibrations. In the Raman spectrum of ettringite, two broad bands without the characteristic bending between $\mathrm{H}_{2} \mathrm{O}$ and $\mathrm{OH}$ stretching vibration were observed. Bands at 3328,3474 , and $3575 \mathrm{~cm}^{-1}$ were recognized based on the second derivative and curve fitting of ettringite vibrational spectra. 
The band assigned to hydroxyl vibration was at $3638 \mathrm{~cm}^{-1}$ (Figure 2a). There were no bands in the $1800-3000 \mathrm{~cm}^{-1}$ range of the Raman spectra of the investigated phases. OH bending vibrations, presented as very weak bands, were noted at $1677 \mathrm{~cm}^{-1}$ and $1682 \mathrm{~cm}^{-1}$ for ettringite and bentorite, respectively (Figure 2a,b).

The hexagonal prismatic crystals of the minerals corresponded to the bentorite-ettringite series from Ma'ale Adummim locality were characterized by the gradual substitution of $\mathrm{Al}$ by $\mathrm{Cr}^{3+}$, which was reflected in the color change from colorless (ettringite) to dark-violet (bentorite) (Figure 2e). The Raman spectrum of dark-violet bentorite (the base part of the crystal showed $\mathrm{Cr}>\mathrm{Al}$ ) (Figure 2c) was almost identical to the bentorite spectrum from Arad Stone locality (Figure $2 b$ ). Small differences were observed in the spectral range associated with asymmetric bending vibrations $v_{4}$ of the $\left(\mathrm{SO}_{4}\right)^{2-}$ group, which were weakened in bentorite from Ma'ale Adummim, and instead of the one band, we observed two at 598 and $641 \mathrm{~cm}^{-1}$ (Figure 2c). Moreover, the low intensity band connected with Al-OH bending vibrations at $853 \mathrm{~cm}^{-1}$ was revealed in this spectrum. It is highly probable that the presence of this band was connected with the crystal orientation during the measurements because it was also observed in the spectrum of the transparent part of the crystal (Figure 2d). The colorless part of the crystal $(\mathrm{Al}>\mathrm{Cr}$ ) was identified as ettringite (Figure $2 \mathrm{~d}$ ). Its Raman spectrum was very similar to the spectrum presented in Figure 2a. Differences were noted in the intensity of bands and the presence of a band at $1065 \mathrm{~cm}^{-1}$, which was attributed to the symmetric stretching vibrations $v_{1}$ of the $\left(\mathrm{CO}_{3}\right)^{2-}$ group.

\subsection{Crystal Structure}

The recently reported structure of $\mathrm{Cr}^{3+}$ rich ettringite [4] was used as a starting model for a crystal structure refinement. In bentorite, as well as in ettringite, two fully occupied Ca sites within the crystal structure were coordinated by four water molecules and four hydroxyl groups, which belonged to the two neighbor $\mathrm{M}$ sites. Two octahedral $\mathrm{M}$ sites, coordinated by six $\mathrm{OH}$ groups, were occupied by $\mathrm{Cr}, \mathrm{Al}$, and Si. Due to the similarity of the scattering factors of Al and Si, their actual occupancies could not be satisfactorily determined. The population refinement was performed only for $\mathrm{Cr}$ and $\mathrm{Al}$, converging for both sites at $\sim 80 \%$ and $\sim 20 \%$, respectively (Supplemental Table S1). Columns of Cr/Al-octahedra and Ca-polyhedra were oriented along the $c$-axis, and they were interconnected by hydrogen bonds to the anion groups within the channels (Figure 3).
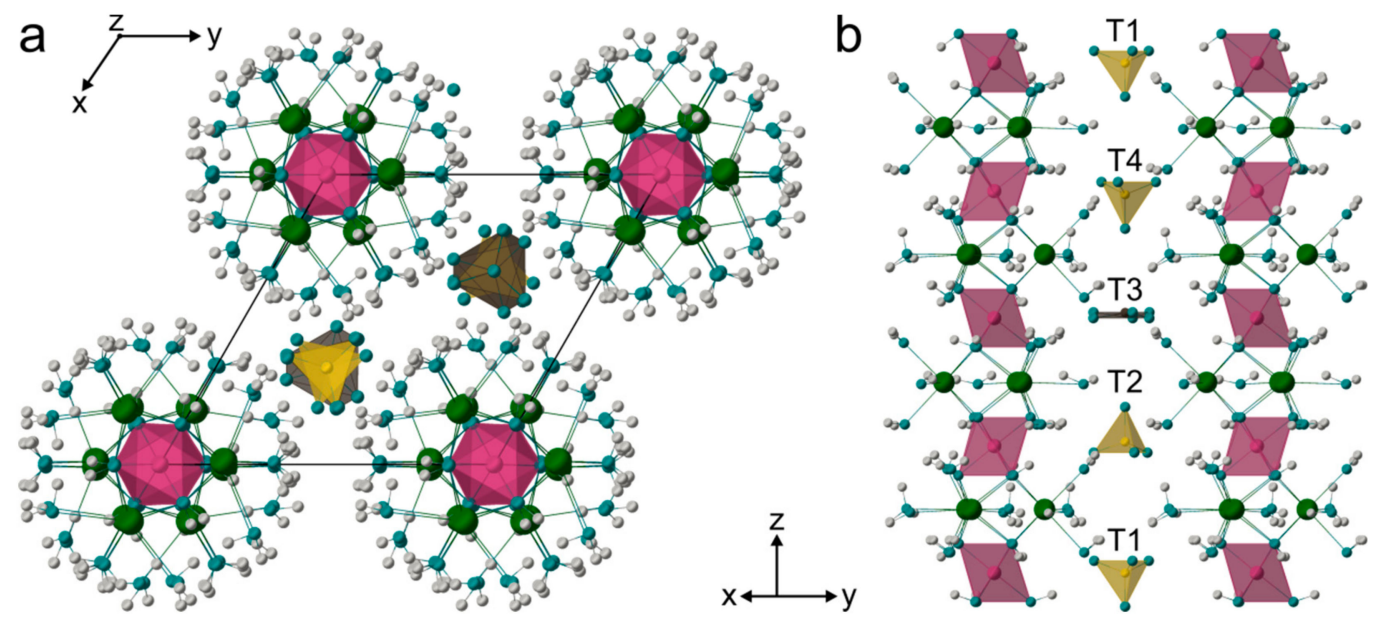

Figure 3. Crystal structure of bentorite: projection along [001] (a) and [110] (b). Ca atoms are green, $\mathrm{Cr}(\mathrm{OH})_{6}$ octahedra in violet, $\left(\mathrm{SO}_{4}\right)^{2-}$ tetrahedra in yellow, and $\left(\mathrm{CO}_{3}\right)^{2-}$ triangles in dark grey. Oxygen and hydrogen atoms are shown as marine and grey spheres, respectively.

The anion groups in the bentorite structure were distributed over four possible positions along $(1 / 3,2 / 3, \mathrm{z})$ and $(2 / 3,1 / 3, \mathrm{z})$. Just as in $\mathrm{Cr}^{3+}$ rich ettringite [4], these positions were occupied by $\left(\mathrm{SO}_{4}\right)^{2-}$, 
$\left(\mathrm{CO}_{3}\right)^{2-}$, and $\mathrm{H}_{2} \mathrm{O}$ molecules. However, in bentorite, the distribution of the groups along the channels was different. With a subsequent analysis of bond lengths, site occupancies, and difference Fourier maps we came to the following conclusions:

A lower electron density at the $\mathrm{T} 1$ site indicated that a part of the $\left(\mathrm{SO}_{4}\right)^{2-}$ tetrahedra could be replaced by a $\left(\mathrm{CO}_{3}\right)^{2-}$ group. The refinement converged at $94 \% \mathrm{~S}$ and $6 \% \mathrm{C}$ (Supplemental Table S1). O13, the apical oxygen of the $\mathrm{S1O}_{4}$ tetrahedra, did not show any significant deviation from full occupancy. However, the oxygen in the basal plane (O16), with three equivalent positions around the three-fold axis, exhibited reduced occupancy of ca. $94 \%$, which was equivalent to the occupancy of the $\mathrm{S} 1$ atom at the $\mathrm{T} 1$ site (Supplemental Table S1). One oxygen atom of the $\left(\mathrm{CO}_{3}\right)^{2-}$ group was located at the $\mathrm{O} 13$ site, as implied by full occupancy of this position. The other oxygen atoms belonging to the carbonate group could not be located, and therefore, the orientation of this planar group could not be determined.

A second anion position T2 was fully occupied by sulfur (S2), which with the four closest oxygen atoms built the $\mathrm{S}_{2} \mathrm{O}_{4}$ tetrahedra with average bond lengths of $1.460 \AA$ (Table 3).

A part of T3, the third anion position in the channel, was occupied by carbon (C3). The nearest oxygen sites (split into O18a and O18b) displayed two different orientations of $\left(\mathrm{CO}_{3}\right)^{2-}$ groups tilted by $\sim 35^{\circ}$ along the c plane. Bond lengths to O18a were slightly longer (1.43(3) $\AA$ ) than the bonds to O18b with $1.41(3) \AA$ A. Modeling this site with $C$ resulted in a refined occupancy of $25 \%$. The occupancies of surrounding oxygen atoms were equal to $0.286(11)$ and $0.411(13)$ for O18a and O18b, respectively (Supplemental Table S1, CIF file). The excess $\mathrm{O}$ atoms may belong to water molecules.

The fourth anion site T4 was again occupied by 0.809(8) sulfur (S4) and 0.191(8) carbon (C4). Consequently, a partial substitution of $\left(\mathrm{SO}_{4}\right)^{2-}$ tetrahedra with $\left(\mathrm{CO}_{3}\right)^{2-}$ groups was evident. The occupancy of the coordinating oxygen atoms revealed the position of the $\left(\mathrm{CO}_{3}\right)^{2-}$ groups. A fully occupied site of the apical oxygen $\mathrm{O} 15$ in $\mathrm{S}_{4} \mathrm{O}_{4}$ tetrahedra and 0.936(8) occupancy of oxygen atom O19 in the basal plane (Supplemental Table S1) revealed that the $\left(\mathrm{CO}_{3}\right)^{2-}$ group was placed parallel to the three faces of the tetrahedra. The $\mathrm{C}_{4} \mathrm{O}_{3}$ group had a shorter bond $\mathrm{O} 15$ (1.453(1) $\AA$ ) and two longer bonds to O19 (1.474(4) $\AA$ ) (Table 3). The charge unbalanced structural formula of the studied bentorite was $\mathrm{Ca}_{6}\left(\mathrm{Cr}_{1.613} \mathrm{Al}_{0.387}\right)_{\Sigma 2}\left[\left(\mathrm{SO}_{4}\right)_{2.75}\left(\mathrm{CO}_{3}\right)_{0.499}\right]_{\Sigma 3.249}(\mathrm{OH})_{12} \cdot 24 \mathrm{H}_{2} \mathrm{O}$ without unsolved water at the $\mathrm{T} 3$ sites.

\subsection{In Situ HT Single Crystal Study}

The evaluation of the high temperature data showed that the crystal was virtually unchanged up to $40{ }^{\circ} \mathrm{C}$. The datasets collected at 35 and $40{ }^{\circ} \mathrm{C}$ exhibited the same lattice parameters (within e.s.d's) and similar average $I / \sigma(I)$ values of the integrated reflections: 26.1 and 25.8, respectively. However, the average $I / \sigma(I)$ at $45^{\circ} \mathrm{C}$ was 9.7 , only, which indicated that the crystal had started to decompose. Comparing the maximum frame intensities of the 40 and $45^{\circ} \mathrm{C}$ measurements revealed that these intensities were decreasing during the $45^{\circ} \mathrm{C}$ data collection. The average $I / \sigma(I)$ value of all reflections at $50{ }^{\circ} \mathrm{C}$ was 1.5. The remaining bentorite Bragg peaks could be detected up to $65^{\circ} \mathrm{C}$. With the onset of the decomposition at $45^{\circ} \mathrm{C}$, weak powder rings occurred. Powder rings originating from randomly oriented crystallites should form spheres in the three dimensional reciprocal space. However, the powder rings of the decomposition product were two-dimensional and oriented perpendicular to $c^{*}$ of the decomposing bentorite crystal. Consequently, one axis of all of the crystallites was still parallel to $c^{*}$. Further, we conclude that this (reciprocal) axis was doubled with respect to bentorite, as only every second layer $(h k l, l=2 \mathrm{n})$ exhibited powder rings. The strongest of the powder rings were observed at d-values of ca. 7.39, 6.02, 4.28, 3.32, and $2.56 \AA$ (Figure 4). 
Table 3. Selected interatomic distances $(\AA)$ in the bentorite structure.

\begin{tabular}{|c|c|c|c|}
\hline \multicolumn{2}{|c|}{ Ca1 } & \multicolumn{2}{|c|}{$\mathrm{Ca} 2$} \\
\hline Ca1-O1 & $2.421(7)$ & $\mathrm{Ca} 2-\mathrm{O} 2$ & $2.443(7)$ \\
\hline Ca1-O1 & $2.462(5)$ & $\mathrm{Ca} 2-\mathrm{O} 2$ & $2.373(5)$ \\
\hline Ca1-O3 & $2.416(5)$ & $\mathrm{Ca} 2-\mathrm{O} 4$ & $2.413(7)$ \\
\hline Ca1-O3 & $2.447(7)$ & $\mathrm{Ca} 2-\mathrm{O} 4$ & $2.390(5)$ \\
\hline Ca1-O6 & $2.400(8)$ & $\mathrm{Ca} 2-\mathrm{O} 5$ & $2.493(8)$ \\
\hline Ca1-O8 & $2.448(8)$ & $\mathrm{Ca} 2-\mathrm{O} 7$ & $2.403(8)$ \\
\hline Ca1-O10 & $2.743(9)$ & Ca2-O9 & $2.597(7)$ \\
\hline $\mathrm{Ca} 1-\mathrm{O} 12$ & $2.675(5)$ & Ca2-O11 & $2.626(4)$ \\
\hline average & 2.502 & average & 2.467 \\
\hline \multicolumn{2}{|c|}{$\mathrm{M} 1=0.799 \mathrm{Cr}+0.201 \mathrm{Al}$} & \multicolumn{2}{|c|}{$\mathrm{M} 2=0.814 \mathrm{Cr}+0.186 \mathrm{Al}$} \\
\hline M1-O1 & $1.985(6)$ & M2-O3 & $1.971(6)$ \\
\hline M1-O1 & $1.985(5)$ & $\mathrm{M} 2-\mathrm{O} 3$ & $1.971(5)$ \\
\hline M1-O1 & $1.985(7)$ & M2-O3 & $1.971(8)$ \\
\hline M1-O2 & $1.951(6)$ & $\mathrm{M} 2-\mathrm{O} 4$ & $1.977(6)$ \\
\hline M1-O2 & $1.951(5)$ & M2-O4 & $1.977(5)$ \\
\hline M1-O2 & $1.951(7)$ & M2-O4 & $1.977(7)$ \\
\hline average & 1.968 & average & 1.974 \\
\hline \multicolumn{4}{|c|}{$\mathrm{T} 1=0.940 \mathrm{~S}+0.060 \mathrm{C}$} \\
\hline & T1-O13 & $1.428(8)$ & \\
\hline & T1-O16 & $1.473(4)$ & \\
\hline & T1-O16 & $1.473(6)$ & \\
\hline & T1-O16 & $1.473(4)$ & \\
\hline & average & 1.462 & \\
\hline \multicolumn{4}{|c|}{$\mathrm{T} 2=\mathrm{S}$} \\
\hline & T2-O14 & $1.482(10)$ & \\
\hline & T2-O17 & $1.452(7)$ & \\
\hline & T2-O17 & $1.452(11)$ & \\
\hline & T2-O17 & $1.452(6)$ & \\
\hline & average & 1.460 & \\
\hline \multicolumn{4}{|c|}{$\mathrm{T} 3=0.25 \mathrm{C}$} \\
\hline T3-O18a & $1.43(3)$ & T3-O18b & $1.413(15)$ \\
\hline T3-O18a & $1.43(3)$ & T3-O18b & $1.41(2)$ \\
\hline T3-O18a & $1.43(2)$ & T3-O18b & $1.413(12)$ \\
\hline average & 1.43 & average & 1.412 \\
\hline \multicolumn{4}{|c|}{$T 4=0.809 \mathrm{~S}+0.191 \mathrm{C}$} \\
\hline & T4-O15 & $1.453(10)$ & \\
\hline & T4-O19 & $1.474(5)$ & \\
\hline & T4-O19 & $1.474(4)$ & \\
\hline & T4-O19 & $1.474(8)$ & \\
\hline & average & 1.469 & \\
\hline
\end{tabular}

Zhou et al. [7] reported on metaettringite as a decomposition product of ettringite. They suggested that the structure of metaettringite was similar to that of despujolsite, $\mathrm{Ca}_{3} \mathrm{Mn}^{4+}\left(\mathrm{SO}_{4}\right)_{2}(\mathrm{OH})_{6} \cdot 3 \mathrm{H}_{2} \mathrm{O}[30]$. A comparison of the d-values of the first strong lines of despujolsite showed a very good match with the d-values of the bentorite decomposition product. Therefore, we suggested the existence of "metabentorite" with a unit cell of ca. $a=b=8.5, c=10.8 \AA$, and a despujolsite-like structure with a likely composition of $\mathrm{Ca}_{6} \mathrm{Cr}_{2}\left(\mathrm{SO}_{4}\right)_{3}(\mathrm{OH})_{12} \cdot 6 \mathrm{H}_{2} \mathrm{O}$. 


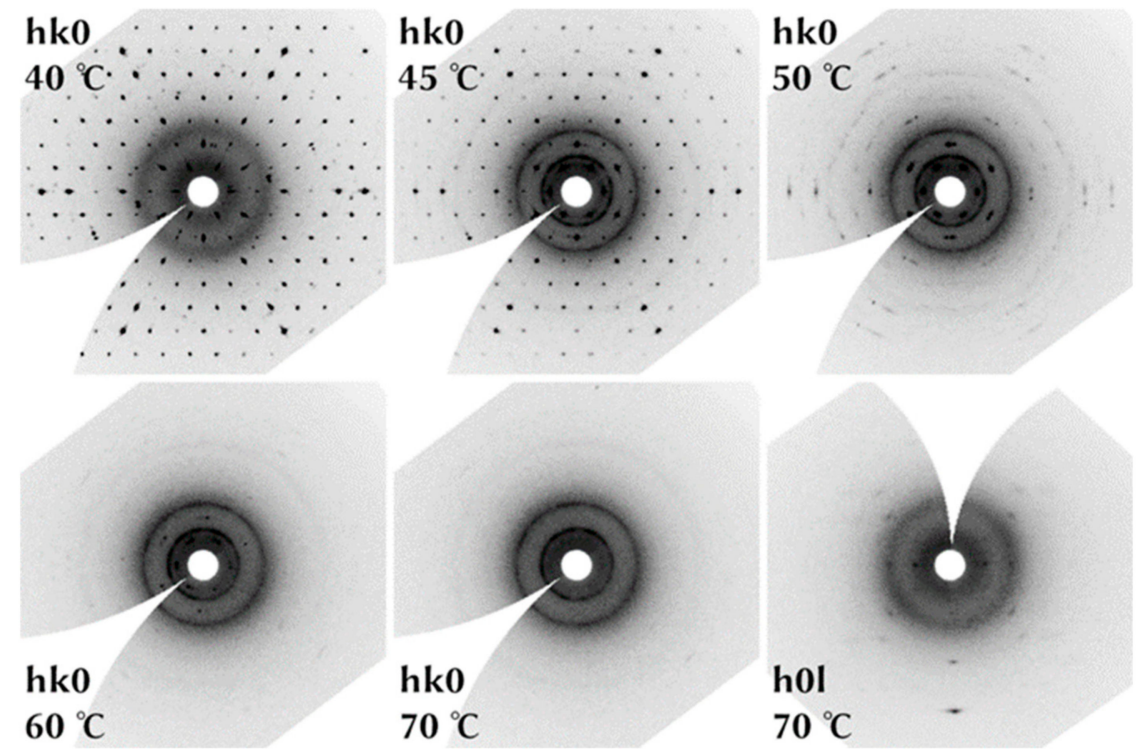

Figure 4. The first five images show the reciprocal space layer $h k 0$ with increasing temperature. Whereas at $40{ }^{\circ} \mathrm{C}$, there are Bragg reflections only, powder rings emerge at $45^{\circ} \mathrm{C}$. At $70{ }^{\circ} \mathrm{C}$, powder rings have completely replaced the Bragg spots. The powder rings do not form spheres in the reciprocal space; instead, they are planar rings. This can be seen in a cross-section $\left(h 0 l\right.$ layer, $70{ }^{\circ} \mathrm{C}, \mathrm{c}^{*}$ vertical, last image). The bentorite crystal decomposed into crystallites with parallel $c^{*}$ axes.

A SEM investigation of the decomposition product revealed a system of cracks, oriented parallel to one direction (Figure 5), which may be created by two-dimensional shrinkage, as discussed by Zhou et al. [7].
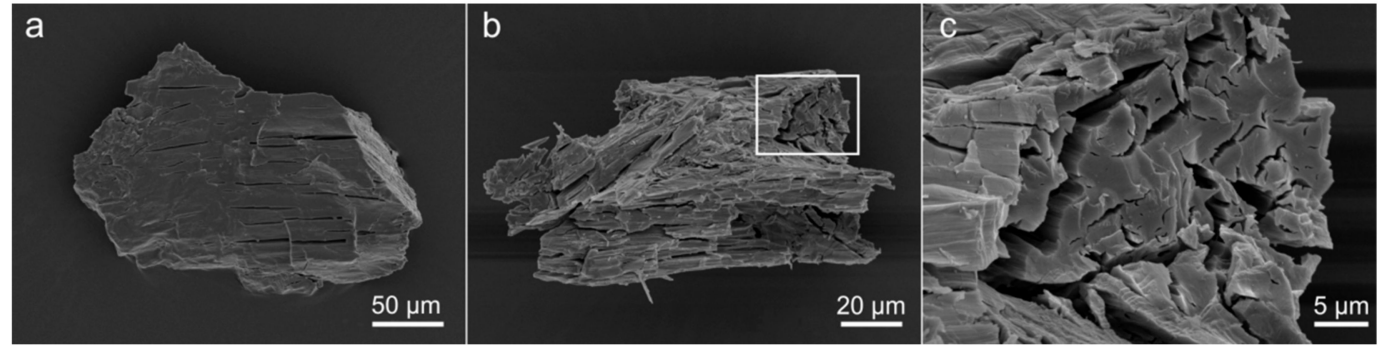

Figure 5. SE images of a bentorite crystal not treated with high temperature (HT) (a), and another crystal after the HT experiments $(\mathbf{b}, \mathbf{c})$. The image (c) shows an enlargement of the region marked in the image (b). After the HT treatment, the material exhibited a significant amount of cracks and fractures, mostly oriented parallel to one axis.

\section{Discussion}

Spectroscopic data for bentorite from the Arad Stone Quarry and Ma'ale Adummim are compared in Table 4. The published spectrum of bentorite [5] could not be used for comparison as the authors incorrectly specified the conditions of the Raman experiment and gave the spectrum of the "burned" phase after bentorite. Supplementary Figure S1 exhibits spectra for the bentorite grain at low and high laser power, and the spectrum of the heated, transformed bentorite (Figure S1b) was the same as presented by Seryotkin et al. [5].

Figure 2 shows the differences in the number and band positions in the Raman spectra of bentorite and ettringite from the two localities. In ettringite, the stronger band was usually observed at 988-993 $\mathrm{cm}^{-1}$, whereas in bentorite, it was shifted to the lower frequencies $\sim 983 \mathrm{~cm}^{-1}$. A similar effect was observed for $\mathrm{OH}$ stretching vibration when the band at $3635-3638 \mathrm{~cm}^{-1}$ in ettringite spectra was shifted towards lower frequencies $3616-3618 \mathrm{~cm}^{-1}$ in bentorite spectra (Figure 2). 
Table 4. Raman band assignments for bentorite from different localities.

\begin{tabular}{|c|c|c|}
\hline $\begin{array}{l}\text { Bentorite from the } \\
\text { Arad Stone Quarry }\end{array}$ & $\begin{array}{l}\text { Bentorite from Ma'ale } \\
\text { Adummim }\end{array}$ & Band Assignment \\
\hline 157,193 & 160,197 & lattice vibrations \\
\hline 442 & 442 & $v_{2}\left(\mathrm{SO}_{4}\right)^{2-}$ \\
\hline 537 & 538 & $\mathrm{Al} / \mathrm{Cr}-\mathrm{OH}$ stretching vibrations of $\mathrm{Al} / \mathrm{Cr}(\mathrm{OH})_{6}{ }^{3-}$ unit \\
\hline 601 & 598,641 & $v_{4}\left(\mathrm{SO}_{4}\right)_{2}^{-}$ \\
\hline 757 & 756 & hydroxyl deformation vibration of $\mathrm{Cr}-\mathrm{OH}$ units \\
\hline- & 853 & $\mathrm{Al}-\mathrm{OH}$ bending vibrations \\
\hline 983 & 983 & $v_{1}\left(\mathrm{SO}_{4}\right)^{2-}$ \\
\hline 1109 & 1111 & $v_{3}\left(\mathrm{SO}_{4}\right)^{2-}$ \\
\hline 1682 & 1685 & $\begin{array}{c}(\mathrm{OH})^{-} \text {bending } \\
\text { vibration of } \mathrm{H}_{2} \mathrm{O} \text { molecules }\end{array}$ \\
\hline $3314,3400,3469$ & $3295,3384,3475$ & $\begin{array}{l}(\mathrm{OH})^{-} \text {stretching } \\
\text { vibration of } \mathrm{H}_{2} \mathrm{O} \text { molecules }\end{array}$ \\
\hline 3618 & 3616 & $(\mathrm{OH})^{-}$stretching vibration of the $\mathrm{OH}$ units \\
\hline
\end{tabular}

Low temperature synchrotron powder diffraction experiments on natural bentorite samples were performed by Serotkin et al. [5] at 100, 250, and $295 \mathrm{~K}$. As a starting model for the structure refinement of bentorite at $100 \mathrm{~K}$, Seryotkin et al. [5] used the structure of $\mathrm{Cr}^{3+}$ bearing ettringite [4]. In their refinement, both octahedral $\mathrm{M}$ sites were fully occupied by $\mathrm{Cr}$, which confirmed the existence of a continuous solid solution between bentorite, $\mathrm{Ca}_{6} \mathrm{Cr}_{2}\left(\mathrm{SO}_{4}\right)_{3}(\mathrm{OH})_{12} \cdot 26 \mathrm{H}_{2} \mathrm{O}$, and ettringite, $\mathrm{Ca}_{6} \mathrm{Al}_{2}\left(\mathrm{SO}_{4}\right)_{3}(\mathrm{OH})_{12} \cdot 26 \mathrm{H}_{2} \mathrm{O}$. Moreover, the arrangement of all anion groups was ordered as in the ettringite structure.

Our single crystal structure refinement was also based on the $\mathrm{Cr}^{3+}$ bearing ettringite structure [4] as a starting model. The octahedral $\mathrm{M}$ sites in our refinement were occupied by $\mathrm{Cr}, \mathrm{Al}$, and $\mathrm{Si}\left(80 \% \mathrm{of} \mathrm{Cr}^{3+}\right)$, whereas in previous work, this occupation was $100 \%$ of $\mathrm{Cr}^{3+}$. Moreover, we observed the disorder of anionic groups, which were distributed over four $\mathrm{T}$ sites in the channels of the crystal structure.

In general, bentorite exhibited the same structure as $\mathrm{Cr}^{3+}$ bearing ettringite [4]; however, the distribution of three $\left(\mathrm{SO}_{4}\right)^{2-}$ tetrahedra and one $\left(\mathrm{CO}_{3}\right)^{2-}$ in the channels was different (Figure 6). In both structures, partial substitution of $\left(\mathrm{SO}_{4}\right)^{2-}$ for $\left(\mathrm{CO}_{3}\right)^{2-}$ groups in the channels was observed. In the studied bentorite, T1 and T4 sites had an S/C ratio equal to 0.940/0.060 and 0.809/0.191, respectively, while in the structure reported by Seryotkin et al. [4], a similar substitution was noted at the T3 site with the $\mathrm{S} / \mathrm{C}$ ratio of $0.91 / 0.09$. In addition, in $\mathrm{Cr}^{3+}$ bearing ettringite, the $\mathrm{T} 3$ tetrahedron was rotated around the three-fold axis, while the almost fully occupied by sulfur T2 site was rotated through $180^{\circ}$, one relative to the other, according to the occupation of $\mathrm{O} 18$ and $\mathrm{O} 19$ atoms with the ratio $0.80 / 0.20$, respectively (Figure 6a). In turn, in the bentorite structure, the rotation of sites occupied simultaneously by $\left(\mathrm{SO}_{4}\right)^{2-}$ and $\left(\mathrm{CO}_{3}\right)^{2-}$ groups was not affirmed (Figure $\left.6 \mathrm{~b}\right)$. Some similarities were also noted between these two structures, e.g., the $\mathrm{T} 1$ site in the structure performed by Seryotkin et al. [4] and the T2 site in the structure presented in this paper were fully occupied by $\left(\mathrm{SO}_{4}\right)^{2-}$ groups and did not show any type of disorder (Figure 6). Moreover, one of the four sites in both structures was partially occupied by $\left(\mathrm{CO}_{3}\right)^{2-}$ groups, and in $\mathrm{Cr}^{3+}$ bearing ettringite, the occupancy of this site (T4) was equal to 0.119 [4], whereas in bentorite (T3) to 0.25 .

In the obtained structure data for bentorite from the Arad Stone Quarry, an interesting situation was observed in the context of the $\left(\mathrm{CO}_{3}\right)^{2-}$ group's location. For sites in the channels where this group partially occupied positions together with sulfate groups, the planar $\left(\mathrm{CO}_{3}\right)^{2-}$ group was not placed parallel to the base plane of the tetrahedra. Probably these groups were statistically distributed over the three equivalent positions, parallel to three faces of the tetrahedra. The $\mathrm{C}$ atom at the $\mathrm{T} 4$ site was coordinated by the two $\mathrm{O} 19(\mathrm{C}-\mathrm{O}=1.474 \AA$ ) and the one $\mathrm{O} 15$ (apical oxygen, $\mathrm{C}-\mathrm{O}=1.452 \AA$ ). 
These $\mathrm{C}-\mathrm{O}$ distances were much longer than the usual distances in the $\left(\mathrm{CO}_{3}\right)^{2-}$ group [31]. Such an effect was observed in stracherite, $\mathrm{BaCa}_{6}\left(\mathrm{SiO}_{4}\right)_{2}\left[\left(\mathrm{PO}_{4}\right)\left(\mathrm{CO}_{3}\right)\right] \mathrm{F}$, at the substitution of the $\left(\mathrm{PO}_{4}\right)^{3-}$ group by the $\left(\mathrm{CO}_{3}\right)^{2-}$ group [32].

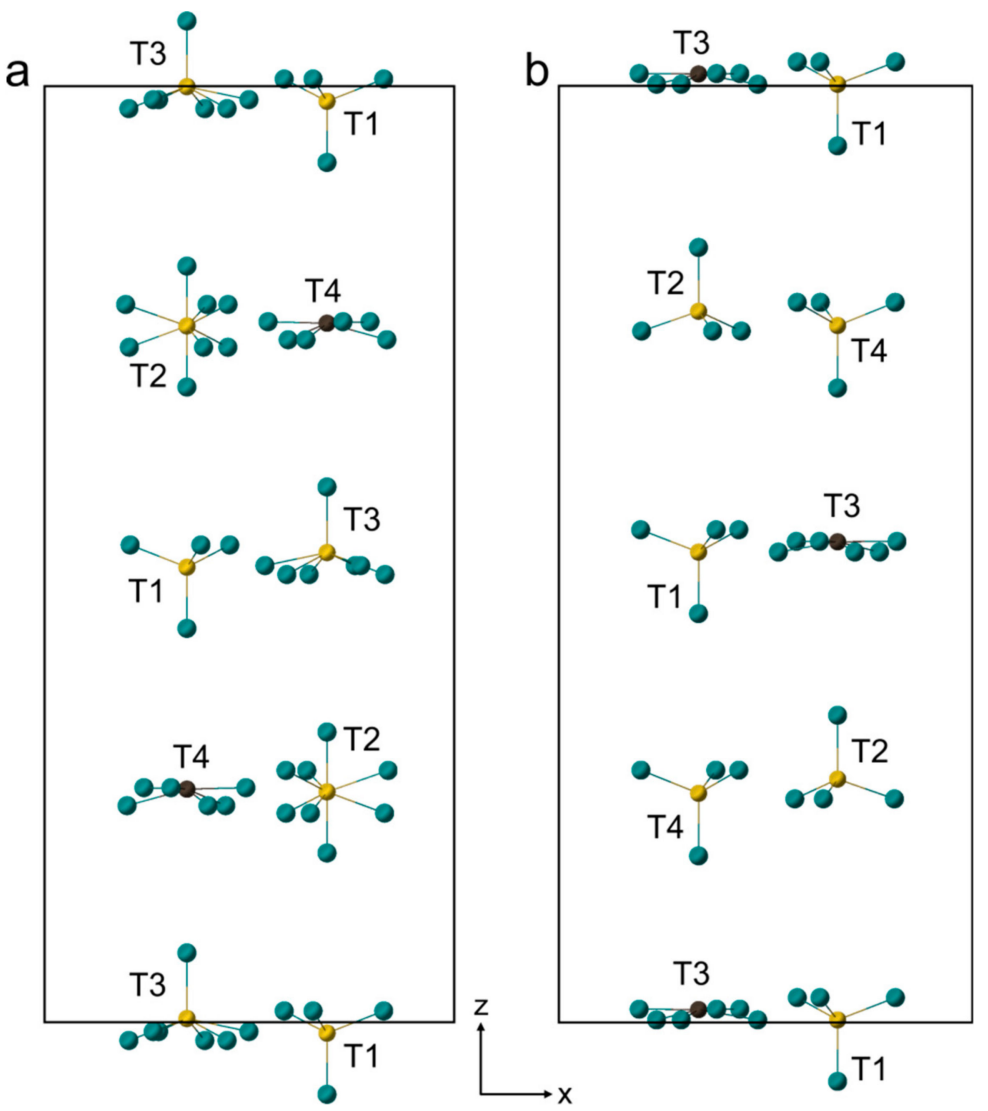

Figure 6. Configuration of the anion $\left(\mathrm{SO}_{4}\right)^{2-}$ and $\left(\mathrm{CO}_{3}\right)^{2-}$ groups in the channels within the structures of $\mathrm{Cr}^{3+}$ bearing ettringite (a) (modified after [4]) and bentorite (b) (present work).

The difference in arrangement and disordering of the anionic groups in channels in the crystal structure of bentorite and $\mathrm{Cr}^{3+}$-bearing ettringite may be related to the occupancies at the $\mathrm{M}$ sites and commonly took place in intermediate members of the ettringite-bentorite solid solution. The presented structure determination showed that the studied bentorite single crystals preserved the unit cell symmetry and structure topology typical of ettringite and confirmed a last missing link in the chain of evidence for ettringite-bentorite solid solution series.

The difference between the ideal formula of bentorite, $\mathrm{Ca}_{6} \mathrm{Cr}_{2}\left(\mathrm{SO}_{4}\right)_{3}(\mathrm{OH})_{12} \cdot 26 \mathrm{H}_{2} \mathrm{O}$, the crystal chemical formula of Arad Stone bentorite calculated on the base of SEM/EDS, $\mathrm{Ca}_{6.00}\left(\mathrm{Cr}_{1.71} \mathrm{Al}_{0.23} \mathrm{Si}_{0.06}\right)\left(\mathrm{SO}_{4}\right)_{3}(\mathrm{OH})_{12} \cdot 26 \mathrm{H}_{2} \mathrm{O}$ (Table 2), and charge unbalanced structural formula, $\mathrm{Ca}_{6}\left(\mathrm{Cr}_{1.613} \mathrm{Al}_{0.387}\right)_{\sum 2}\left[\left(\mathrm{SO}_{4}\right)_{2.75}\left(\mathrm{CO}_{3}\right)_{0.499}\right]_{\sum 3.249}(\mathrm{OH})_{12} \cdot 24 \mathrm{H}_{2} \mathrm{O}$ (Table 1 and Table S1), were needed for the discussion. Chemical data obtained from SEM/EDS were calculated on ideal stoichiometry without taking into consideration carbon (Table 2). The formula received from structural data was not considered unsolved water at the $\mathrm{T} 3$ sites (maximum content $2-{ }^{\mathrm{T} 3}\left(\mathrm{CO}_{3}\right)^{2-}$, Supplemental Table S1). It is possible that additional $\left(\mathrm{CO}_{3}\right)^{2-}$ groups at the $\mathrm{T} 3$ were balanced by the incorporation of an insignificant amount of $\mathrm{Si}^{4+}$ instead of $\mathrm{Cr}^{3+}$ as SEM/EDS data (Table 2) and also decreasing of the $(\mathrm{OH})^{-}$group's content. As mentioned above, it was not possible to refine $\mathrm{Si}$ at the $\mathrm{M}$ site, so we proposed the following crystal chemical formula of the studied bentorite: $\mathrm{Ca}_{6}\left(\mathrm{Cr}_{1.613} \mathrm{Al}_{0.387}\right)_{\sum 2}\left[\left(\mathrm{SO}_{4}\right)_{2.75}\left(\mathrm{CO}_{3}\right)_{0.499}\right]_{\sum 3.249}(\mathrm{OH})_{11.502} \sim 25.75 \mathrm{H}_{2} \mathrm{O}$. 
Supplementary Materials: The following are available online at http://www.mdpi.com/2075-163X/10/1/38/s1. The bentorite_cif. file; Table S1: Atom coordinates' $(x, y, z)$, occupancies and equivalent isotropic displacement parameters $\left(\mathrm{U}_{\mathrm{eq}}, \AA^{2}\right)$ for bentorite from the Arad Stone Quarry; Table S2: Anisotropic displacement parameters $\left(\AA^{2}\right)$ for bentorite from the Arad Stone Quarry. Figure S1: Roman spectra of bentorite received at low (a) and high laser power (b).

Author Contributions: R.J., B.K., and I.G. wrote the paper. R.J. performed the petrological investigation, measurements of chemical composition (EDS), and Raman studies. H.K. and C.K. performed SC-XRD and HT single crystal investigation of the bentorite structure. M.T. performed the SEM analysis after the HT experiment. All authors have read and agreed to the published version of the manuscript.

Funding: The investigations were supported by the National Science Centre (NCN) of Poland, Grant No. 2016/23/N/ST10/00142 (R.J.).

Acknowledgments: The authors would like to thank Yevgeny Vapnik for collecting the bentorite samples. The authors also thank the anonymous reviewers for their useful and constructive comments, which allowed improving a previous version of the manuscript.

Conflicts of Interest: The authors declare no conflict of interest.

\section{References}

1. Gross, S. Bentorite-a new mineral from the Hatrurim area, west of the Dead Sea, Israel. Isr. J. Earth Sci. 1980, $29,81-84$.

2. Wieczorek-Ciurowa, K.; Fela, K.; Kozak, A.J. Chromium(III)-Ettringite Formation and its Thermal Stability. J. Therm. Anal. Calorim. 2001, 65, 655-660. [CrossRef]

3. Juroszek, R.; Krüger, B.; Galuskina, I.O. Structural reinvestigation of bentorite. In Mitteilungen der Österreichischen Mineralogischen Gesellschaft; Universität Innsbruck: Innsbruck, Austria, 2017; Volume 163, p. 49.

4. Seryotkin, Y.V.; Sokol, E.V.; Kokh, S.N.; Murashko, M.N. Natural $\mathrm{Cr}^{3+}$-rich ettringite: Occurrence, properties, and crystal structure. Phys. Chem. Miner. 2018, 45, 279-292. [CrossRef]

5. Seryotkin, Y.V.; Sokol, E.V.; Kokh, S.N.; Sharygin, V.V. Natural bentorite- $\mathrm{Cr}^{3+}$ derivate of ettringite: Determination of crystal structure. Phys. Chem. Miner. 2019, 46, 553-570. [CrossRef]

6. Drebushchak, V.A.; Seryotkin, Y.V.; Kokh, S.N.; Sokol, E.V. Natural specimen of triple solid solution ettringite-thaumasite-chromate-ettringite. J. Therm. Anal. Calorim. 2013, 114, 777-783. [CrossRef]

7. Zhou, Q.; Lachowski, E.E.; Glasser, F.P. Metaettringite, a decomposition product of ettringite. Cem. Concr. Res. 2004, 34, 703-710. [CrossRef]

8. Bentor, Y.K.; Gross, S.; Heller, L. Some unusual minerals from the "Mottled Zone" complex, Israel. Am. Mineral. 1963, 48, 924-930.

9. Gross, S. The Mineralogy of the Hatrurim Formation, Israel; Geological Survey of Israel: Jerusalem, Israel, 1977.

10. Burg, A.; Starinsky, A.; Bartov, Y.; Kolodny, Y. Geology of the Hatrurim Formation ("Mottled Zone") in the Hatrurim basin. Isr. J. Earth Sci. 1991, 40, 107-124.

11. Techer, I.; Khoury, H.N.; Salameh, E.; Rassineux, F.; Claude, C.; Clauer, N.; Pagel, M.; Lancelot, J.; Hamelin, B.; Jacquot, E. Propagation of high-alkaline fluids in an argillaceous formation: Case study of the Khushaym Matruk natural analogue (Central Jordan). J. Geochem. Explor. 2006, 90, 53-67. [CrossRef]

12. Sokol, E.; Novikov, I.; Zateeva, S.; Vapnik, Y.; Shagam, R.; Kozmenko, O. Combustion metamorphism in the Nabi Musa dome: New implications for a mud volcanic origin of the Mottled Zone, Dead Sea area. Basin Res. 2010, 22, 414-438. [CrossRef]

13. Geller, Y.I.; Burg, A.; Halicz, L.; Kolodny, Y. System closure during the combustion metamorphic "Mottled Zone" event, Israel. Chem. Geol. 2012, 334, 25-36. [CrossRef]

14. Novikov, I.; Vapnik, Y.; Safonova, I. Mud volcano origin of the Mottled Zone, South Levant. Geosci. Front. 2013, 4, 597-619. [CrossRef]

15. Matthews, A.; Gross, S. Petrological Evolution of the "Mottled Zone" (Hatrurim) Metamorphic Complex of Israel. Isr. J. Earth Sci. 1980, 29, 93-106.

16. Grapes, R. Pyrometamorphism, 2nd ed.; Springer: Heidelberg/Berlin, Germany, 2010; ISBN 978-3-642-15587-1.

17. Khoury, H.N.; Sokol, E.V.; Clark, I.D. Calcium uranium oxide minerals from Central Jordan: Assemblages, chemistry, and alteration products. Can. Mineral. 2015, 53, 61-82. [CrossRef] 
18. Kolodny, Y.; Burg, A.; Geller, Y.I.; Halicz, L.; Zakon, Y. Veins in the combusted metamorphic rocks, Israel; Weathering or a retrograde event? Chem. Geol. 2014, 385, 140-155. [CrossRef]

19. Clark, R.C.; Reid, J.S. The analytical calculation of absorption in multifaceted crystals. Acta Crystallogr. Sect. A 1995, 51, 887-897. [CrossRef]

20. Rigaku Oxford Diffraction. CrysAlisPro Software System, Version 1.171.38.43; Rigaku Corporation: Oxford, UK, 2015.

21. Petříček, V.; Dušek, M.; Palatinus, L. Crystallographic Computing System JANA2006: General features. Z. Krist. Cryst. Mater. 2014, 229, 345-352. [CrossRef]

22. Krüger, H.; Breil, L. Computer-controlled high-temperature single-crystal X-ray diffraction experiments and temperature calibration. J. Appl. Cryst. 2009, 42, 140-142. [CrossRef]

23. Stoe. Cie X-AREA 1.84; Stoe \& Cie GmbH: Darmstadt, Germany, 2018.

24. Myneni, S.C.B.; Traina, S.J.; Waychunas, G.A.; Logan, T.J. Vibrational spectroscopy of functional group chemistry and arsenate coordination in ettringite. Geochim. Cosmochim. Acta 1998, 62, 3499-3514. [CrossRef]

25. Renaudin, G.; Segni, R.; Mentel, D.; Nedelec, J.-M.; Leroux, F.; Taviot-Gueho, C. A Raman Study of the Sulfated Cement Hydrates: Ettringite and Monosulfoaluminate. ACT 2007, 5, 299-312. [CrossRef]

26. Frost, R.L.; López, A.; Xi, Y.; Scholz, R.; da Costa, G.M.; Lima, R.M.F.; Granja, A. The spectroscopic characterization of the sulphate mineral ettringite from Kuruman manganese deposits, South Africa. Vib. Spectrosc. 2013, 68, 266-271. [CrossRef]

27. Scholtzová, E.; Kucková, L.; Kožíšek, J.; Tunega, D. Structural and spectroscopic characterization of ettringite mineral-combined DFT and experimental study. J. Mol. Struct. 2015, 1100, 215-224. [CrossRef]

28. You, K.S.; Ahn, J.W.; Cho, H.C.; Han, G.C.; Han, D.Y.; Cho, K.H. Competing Ion Effect of Stabilization by $\mathrm{Cr}(\mathrm{III})$ \& Cr(VI) in Ettringite Crystal Structure. Solid State Phenom. 2007, 124-126, 1629-1632.

29. Kloprogge, J.T.; Hickey, L.; Frost, R.L. The effect of varying synthesis conditions on zinc chromium hydrotalcite: A spectroscopic study. Mater. Chem. Phys. 2005, 89, 99-109. [CrossRef]

30. Barkley, M.C.; Yang, H.; Evans, S.H.; Downs, R.T.; Origlieri, M.J. Redetermination of despujolsite, $\mathrm{Ca}_{3} \mathrm{Mn}^{4+}\left(\mathrm{SO}_{4}\right)_{2}(\mathrm{OH})_{6} \cdot 3 \mathrm{H}_{2} \mathrm{O}$. Acta Crystallogr. Sect. E 2011, 67, i47-i48. [CrossRef] [PubMed]

31. Antao, S.M.; Hassan, I. Temperature dependence of the structural parameters in the transformation of aragonite to calcite, as determined from in situ synchrotron powder X-ray-diffraction data. Can. Mineral. 2010, 48, 1225-1236. [CrossRef]

32. Galuskin, E.V.; Krüger, B.; Galuskina, I.O.; Krüger, H.; Vapnik, Y.; Pauluhn, A.; Olieric, V. Stracherite, $\mathrm{BaCa}_{6}\left(\mathrm{SiO}_{4}\right)_{2}\left[\left(\mathrm{PO}_{4}\right)\left(\mathrm{CO}_{3}\right)\right] \mathrm{F}$, the first $\mathrm{CO}_{3}$-bearing intercalated hexagonal antiperovskite from Negev Desert, Israel. Am. Mineral. 2018, 103, 1699-1706. [CrossRef]

(C) 2019 by the authors. Licensee MDPI, Basel, Switzerland. This article is an open access article distributed under the terms and conditions of the Creative Commons Attribution (CC BY) license (http://creativecommons.org/licenses/by/4.0/). 